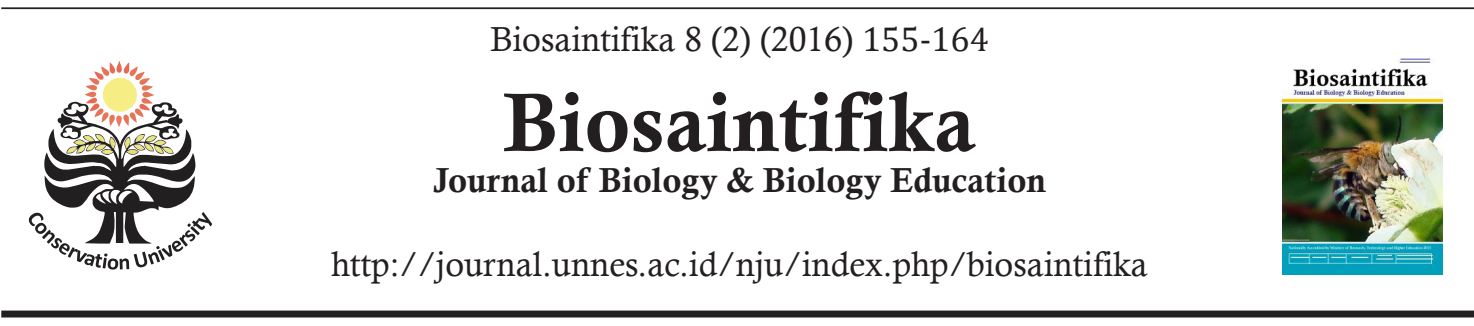

\title{
Protein Profile and Hematological Parameters of Mice post Injected with Irradiated Plasmodium berghei
}

\author{
${ }^{\otimes}$ Imam Rosadi ${ }^{1}$, Mukh Syaifudin $^{2}$, Dewi Elfidasari ${ }^{1}$
}

DOI: 10.15294/biosaintifika.v8i2.6341

${ }^{1}$ Department of Biology, Faculty of Science and Technology, University of Al Azhar Indonesia, Indonesia ${ }^{2}$ Center for Technology of Radiation Safety and Metrology, National Nuclear Energy Agency, Indonesia

\section{History Article \\ Received 13 February 2016 Approved 16 June 2016 Published 1 September 2016}

\section{Keywords:}

malaria vaccine; irradiation; Plasmodium berghei; leucocyte and erythrocyte; protein profiles

\begin{abstract}
Indonesia had a high number of malaria cases where the treatments are only perceived by $10 \%$ of patients in health facilities. The resistance of Plasmodium $s p$. to drugs causes the difficulty of controlling malaria. The use of irradiation to produce malaria vaccine material is being explored until nowadays. In previously study tha dose rate of gamma irradiation delivered to parasite at the low dose rate (380 Gy/ hour) which produced several doses that not be able to attenuate the parasite. This research aimed to increase dose rate (740 Gy/hour) and to determine the effect of dose irradiation effect of 150-250 Gy to the protein profile, erythrocyte and leukocyte numbers in mouse blood infected by $P$. berghei erythrocytic stage. Results showed that there was an influence of dose rate of $740 \mathrm{~Gy} /$ hour for doses of 150$250 \mathrm{~Gy}$ in treated mice and no different in erythrocyte, leucocyte and body weight with negative control. Dose of $150 \mathrm{~Gy}$ was the optimal dose to attenuate parasites, whereas doses more than 150 Gy effectively killed the parasites. The changes of protein profile marked by the appearance of higher number of bands at molecular weight of $30-37 \mathrm{kDa}$ that predicted as merozoite surface protein of P. berghei and/ or antibodies elicited in mouse.
\end{abstract}

\section{How to Cite}

Rosadi, I., Syaifudin, M., \& Elfidasari, D. (2016). Protein Profile and Hematological Parameters of Mice post Injected with Irradiated Plasmodium berghei. Biosaintifika: Journal of Biology \& Biology Education, 8(2), 155-164.

C 2016 Semarang State University

Correspondence Author:

p-ISSN 2085-191X

J1. Sisingamangaraja, Kebayoran Baru Jakarta Selatan, 12110

e-ISSN 2338-7610 
Imam Rosadi, Mukh Syaifudin, Dewi Elfidasari / Biosaintifika 8 (2) (2016) 155-164

\section{INTRODUCTION}

Southeast Asia is one of the regions with high mortality rate of malaria. There are 28 million cases of malaria found in Southeast Asia from 216 million cases in the world in 2010 (Autino et al., 2012). Indonesia as the island nation that located in the South-East Asian region has quite high prevalence (number of events) of malaria. It is noted that Indonesia have a number of malaria paining of 1.85 per 1,000 inhabitants in 2009 . Treatments of malaria are only perceived by $10 \%$ of the total number of patients in health facilities (KEMENKES 2011).

Malaria is a disease that can be found in animals and human which caused by protozoa of obligate intracellular of Plasmodium infection. There are four Plasmodium sp. that infecting human namely a Plasmodium ovale, Plasmodium malariae, Plasmodium vivax and Plasmodium falciparum. Plasmodium falciparum is the most dangerous parasite because it can cause of death in children and pregnant women (Zuzarte-Luis, Mota, \& Vigário 2014; Lamikanra et al., 2007; Krishna et al., 2015).

Plasmodium sp. in human has similarities in morphology, genetic and life cycle with Plasmodium sp. that attacks animals. This is the basis of research in parasitological, immunology and the malaria vaccine development using an animal model of rodent such as mouse (Mlambo and Kumar 2008). There were two phases of Plasmodium development that divided into schizonts and sporogony phases. The main points of both phases are parasite pathogenicity infection from host to vector and vector to host (Antino et al., 2012; Delves et al., 2012). Based on their life cycle of infection into human/animals body that there were divided into three phases namely liver stage, blood stage, and vector stage (Delves et al., 2012).

In the blood stage, Plasmodium released merozoites into circulation to invade blood cells. The number of merozoites that released by Plasmodium depend into species of Plasmodium to perpetuate the asexual life cycle. Plasmodium are also released a large amount of toxins that cause the innate immunity activation. The most dangerous of Plasmodium blood stage also showed by manifestations (cerebral malaria or anemia) and cytoadherence ability. Cytoadeherence is the ability of parasite to adhere with several organs vascular endothelium (lung, heart, brain, liver and kidney), placenta and subcutaneous adipose tissue (Antino et al., 2012).

In this study, we developed our research about Plasmodium berghei that has a level of vi- olence similar to $P$. falciparum which causes death in the blood stage. P. berghei is a parasite that attacks the rodents. The parasite $P$. berghei has been widely used for malaria vaccine development research (Mlambo \& Kumar 2008; Demicheli et al., 2006; Jobe et al., 2007). The resistance of Plasmodium sp. to drugs and malarial mosquitoes to the insecticides causes the difficulty of controlling malaria. The alternative to prevent of malaria disease is vaccine (Asih et al., 2012).

Research on vaccine with irradiation has started since 1967 by Nussenzweig that immunization of mice with irradiated sporozoit of $P$. berghei capable of protecting challenges with infective sporozoit (Hill, 2011; Crompton et al., 2010). Infective sporozoit that exposed to irradiation has suffered damage to the structure of the protein. Changes in the structure of this protein can be caused by protein denaturation, protein degradation or alteration of the structure of DNA (deoxyribonucleic acid). Changes in DNA structure can cause a particular protein synthesis or it generates new proteins (Tetriana et al., 2008).

Dose and dose rate of irradiation affecting the attenuation of infective parasites. The research that has been done previously in our laboratory was only at the low dose rate (380 $\mathrm{Gy} / \mathrm{h}$ ), but there is no information after irradiation at high doses rate (more than $700 \mathrm{~Gy} / \mathrm{h}$ ) on protein expression/profile alteration (Tetriana et al.,2008; Darlina \& Tetriana 2006; Syaifudin et al., 2008; Syaifudin et al., 2013). Protein profile test was needed to be conducted to determine the security levels of the irradiated samples and its purity.

It still needs to test protein profiles of $P$. berghei of erythrocytes stage through the analysis with SDS-PAGE (Sodium Dodecyl Sulfate-Polyacrylamide Gel Electrophoresis) at certain doses of irradiation. Based on previous studies, doses of irradiation of $75-125 \mathrm{~Gy}$ are not effective to weaken the P. berghei in red blood cells (Darlina \& Tetriana 2006). The optimum dose of irradiation was 150 to $175 \mathrm{~Gy}$ at dose rate of $380 \mathrm{~Gy} /$ hour. The optimal dose is the dose that can lower the infectiousness of Plasmodium in red blood cells of mice (Darlina and Tetriana 2006; Hoffman et al., 2002). Up to now there is no available data on protein profiles of P.berghei irradiated with doses of $0 \mathrm{~Gy}$ (positive control), 150, 175, 200 and 250 Gy at dose rate of $740 \mathrm{~Gy} / \mathrm{h}$. On this basis, it is necessary to do research aimed of analysis SDSPAGE, erythrocyte and leucocyte number at high dose rate with doses of radiation are 150, 175, 200 and 250 Gy to get dose optimal of malaria vaccine. The dose optimal can be reviewed that 
vaccine candidate also has characteristic as active or inactive vaccine. In the future, the blood stage of malaria can be prevented by vaccine with utilizing gamma irradiation at the high dose rate which was quickly than the lower dose rate.

\section{METHODS}

\section{Parasites and Mice}

Plasmodium berghei (strain Antwerpen-Kasapa, ANKA) infected mouse bloods were received from Eijkman Institute for Molecular Biology in Jakarta. Male Swiss-Webster mice (6-8 weeks old at the beginning of research) were purchased from SEAMEO TROPMED Regional Center for Community Nutrition University of Indonesia in Jakarta and were housed at the Animal Laboratory of The Center for Technology of Radiation Safety and Metrology, National Nuclear Energy Agency of Indonesia (BATAN) and handled according to institutional guidelines. All procedures were reviewed and approved by the Animal Care and Use Committee National Institute of Health Research and Development, the Indonesian Ministry of Health.

\section{Mice Infection}

Two mice were intraperitoneally (IP) injected with about $1 \times 10^{6} \mathrm{P}$. berghei $/ \mathrm{ml}$ parasitized blood and control mice were sham injected with uninfected blood (negative control) (Figure 1). The number of parasites in the blood (parasitaemia) was monitored by Giemsa stained blood smears using light microscopy. Parasitemia, physical condition and body weight and survival of mice were noted.

\section{Parasitaemia Monitoring}

Parasitemia in mice from each infected group were monitored daily by conventional Giemsa staining starting on day 3 after infection. Thin blood films were prepared by tail bleeding, air dried, and methanol fixed before staining. Staining was done with a $10 \%$ Giemsa solution for 10 minutes at room temperature. Slides were evaluated at a $1000 \times$ magnification (oil-immersion) using a Nikon E200 Eclipse microscope by reading 20 fields per slide.

\section{Irradiation of Blood Stage Parasites}

Infected bloods of mouse with $20-40 \%$ parasitemia were irradiated in vitro within a gamma irradiator (Cobalt-60 of IRPASENA) of the Center for Application of Isotope and Radiation, BATAN to doses of 0 (positive control), 150, 175, 200 and $250 \mathrm{~Gy}$ at a high dose rate $(740.0 \mathrm{~Gy} /$ hour). Each control and treatment groups consist of 3 swiss webster mice.

\section{Erythrocytes and Leukocytes Calculation}

$8 \mu \mathrm{L}$ of blood was taken from the tail end of mice and then $3 \mu \mathrm{L}$ of this blood was dissolved in $493 \mu \mathrm{L}$ of Hayem for the examination of erythrocytes number, and other $5 \mu \mathrm{L}$ was dissolved in $95 \mu \mathrm{L}$ of Turk solution for leukocytes examination. The numbers of erythrocytes and leukocytes count were observed under microscope at 400x and 100x magnifications. The number of erythrocytes and leukocytes was calculated with the following formulas [a] and [b].

Erythrocyte $\left(\right.$ cell $\left./ \mathrm{mm}^{3}\right)=\left(\Sigma\right.$ cell $\left.\times \mathrm{DF}^{*}\right) /(0.0025$ $\mathrm{mm}^{2}$ x $\left.0.1 \mathrm{~mm}\right)$.

Leucocyte $\left(\right.$ cell $\left./ \mathrm{mm}^{3}\right)=\left(\sum\right.$ cell $\left.\times \mathrm{DF}^{*}\right) /\left(0.01 \mathrm{~mm}^{2}\right.$ $\mathrm{x} 0.1 \mathrm{~mm})$.

\section{$\mathrm{DF}^{*}=$ Dilution Factor}

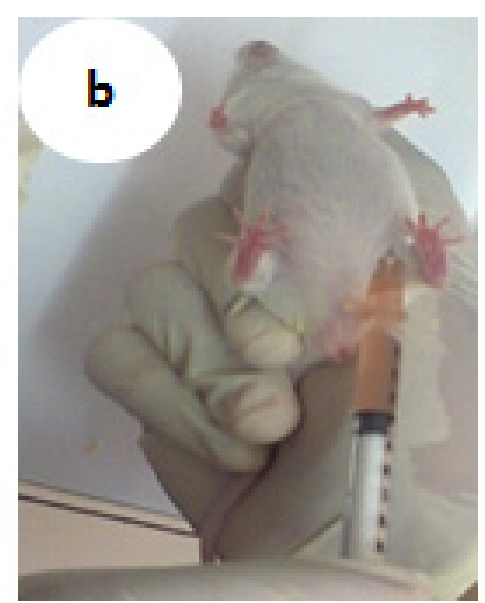

Figure 1. $P$. berghei breeding process, (a) mice holding tehcnique; (b) intraperitonelly injection of $P$. berghei

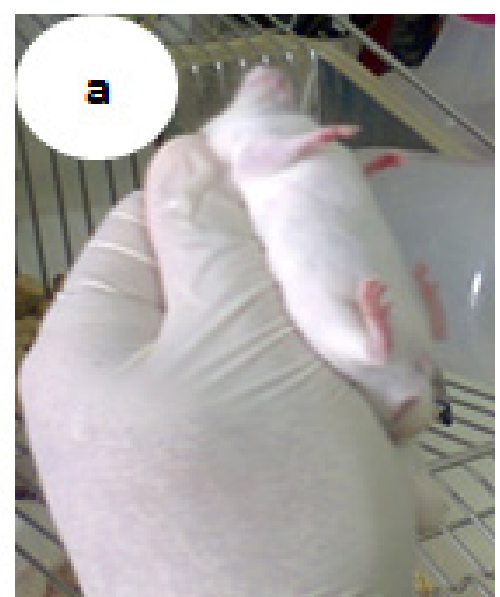




\section{Sodium Dodecyl Sulfate-Polyacrylamide Gel Electrophoresis (SDS-PAGE)}

Electrophoresis.SDS-PAGE was performed according to the methods of Laemmli, 1970 (Hoffman et al., 2002) and Theisen to the following group of samples: doses and dose rates of gamma ray for irradiation of $P$. berghei and days post infection and percentage of parasite density for non irradiated parasites. It was carried out on Bio-Rad gels composed of stacking gel (5\% $\mathrm{w} / \mathrm{v})$ using 1.0 M Tris-glycine buffer containing $0.4 \%$ SDS at $\mathrm{pH} 6.8$ and resolving gel $(12 \%, \mathrm{w} / \mathrm{v})$ using $1.5 \mathrm{M}$ Tris-glycine buffer containing $0.4 \%$ $\mathrm{SDS}$ at $\mathrm{pH}$ 8.8. Protein sample was dissolved in phosphate buffer $(5 \mathrm{mg} / \mathrm{ml})$ and mixed with $6.22 \mu \mathrm{l}$ of solubilization Tris- $\mathrm{HCl}$ buffer $(\mathrm{pH}$ 6.8) which contains $2 \%(\mathrm{w} / \mathrm{v})$ SDS, $50 \%$ glycerol, a pinch of bromophenol blue and reduced with $0.9 \mu 1$ of 2-mercaptoethanol in boiling water for $5 \mathrm{~min}$. Protein sample was loaded onto each well of the acrylamide gel and electrophoresis (BioRad Laboratories, Hercules, CA) was conducted at constant current of 100 volts for 90 minutes by a Bio-Rad electrophoresis power supply unit. A standard broad range of protein marker was also run into every gel. After electrophoresis, gels were stained with Commassie-250 blue solution for one night and then was fixed with fixative solution (methanol: acetic acid $=3: 1$ ) for 1 hour and in the water for another 1 hour and photographed with Gel-doc imaging system (Bio-rad).

To determine molecular weights of protein, a standard curve was constructed from the distances migrated by each marker protein. Then the distance migrated by the sample proteins can be plotted and their molecular weights calculated by interpolation with Excel Program.

\section{RESULTS AND DISCUSSION}

\section{Plasmodium berghei Breeding}

$P$. berghei harvested after reaching more than $30 \%$ parasitaemia, with an average of $34.03 \%$ on day 14 (Table 1). Blood containing $34.03 \%$ parasite then prepared for the positive control and irradiation. Treatment of blood samples were irradiated with high dose rate 740 Gy/hour respectively divided in a dose of 150
Gy, 175 Gy, 200 Gy and 250 Gy.

\section{Mice Physical Observation}

The experiment showed that appearance of physical symptoms in mice was occured only in positive control (non-irradiated) group during the first two weeks following inoculation of parasites. These symptoms included mucous membrane echidna, paler toes and tail of mice infected with non irradiated $P$. berghei. Whereas mice injected with irradiated parasites at doses of 150-250 Gy did not show any symptoms of clinical effects that may caused by the weakness of parasites after irradiation to infect red blood cells. Clinical symptoms were not seen in this treated mice group that might be caused by the exposure to high dose rate $(740 \mathrm{~Gy} / \mathrm{h})$ and result in dead of parasites. Symptoms seen on negative control mice were the decreasing of appetite and drink and their body weight (Lamikanra et al., 2007, Darlina \& Tetriana 2006; Basir et al., 2015) (Figure 2).

\section{Erythrocytes and Leukocytes Calculation}

Results of calculation of erythrocytes and leukocytes indicated that the negative control mice had the highest number of erythrocytes, while the positive control group had the lowest number of erythrocytes (Figure 3). Erythrocytes number in blood of mice that infected with irradiated P. berghei (150, 175, 200 and $250 \mathrm{~Gy})$ was higher than the positive control but lower than that of the negative control. As seen in Figure 3 that the number erythrocytes in blood of positive control mice was decreased started on day 8 and get steady number until day 28 post infection.

Leukocytes are the cells of the immune system that are involved in defending the body against both infectious disease and foreign invaders such as parasites (Spiering, 2015). The number of leukocytes in each treatment group did not show any difference among them, except for positive control. Positive control mice had an increased number of leukocytes from day 3 and relatively stable on the day of the 8 th to 12 th. The very high number of leukocytes was observed on days 14 and 16 (Figure 4). Increased number of leukocytes is due to the response of immune reac-

Table 1. Parasitemia before irradiation on day 14

\begin{tabular}{lllc}
\hline Red Blood Cell (RBC)/ Erythrocytes & Parasite & $($ Parasite/RBC) x 100 & $\begin{array}{l}\text { Percentage of } \\
\text { Parasite }\end{array}$ \\
\hline 2198 & 824 & $(824 / 2198) \times 100$ & 37.49 \\
2207 & 675 & $(675 / 2207) \times 100$ & 30.58 \\
Average & 749.5 & $(749.5 / 22022) \times 100$ & 34.03 \\
\hline
\end{tabular}




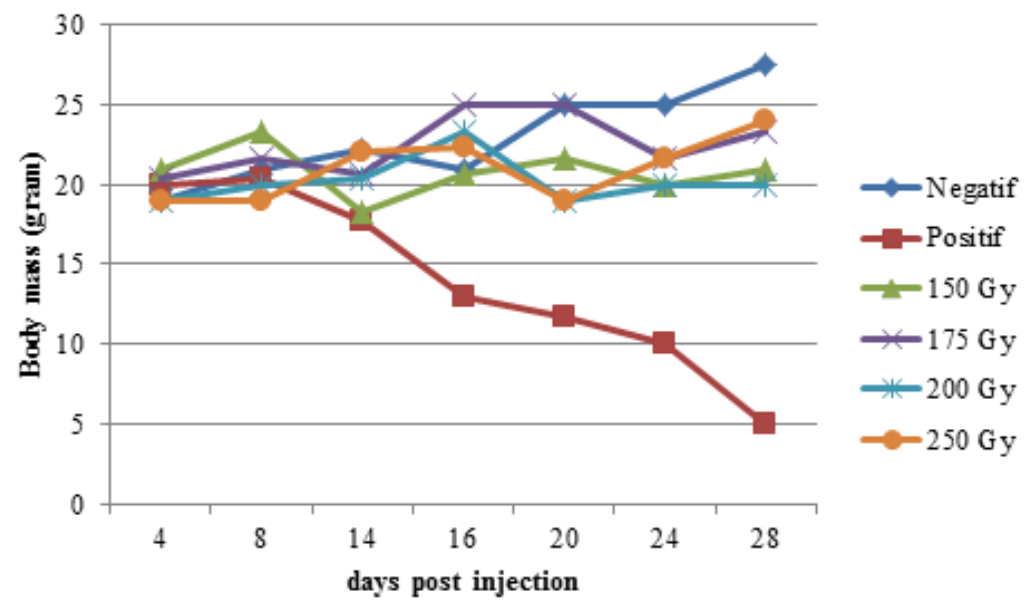

Figure 2. Body weight of mouse at days post injection with gamma irradiated $P$. berghei

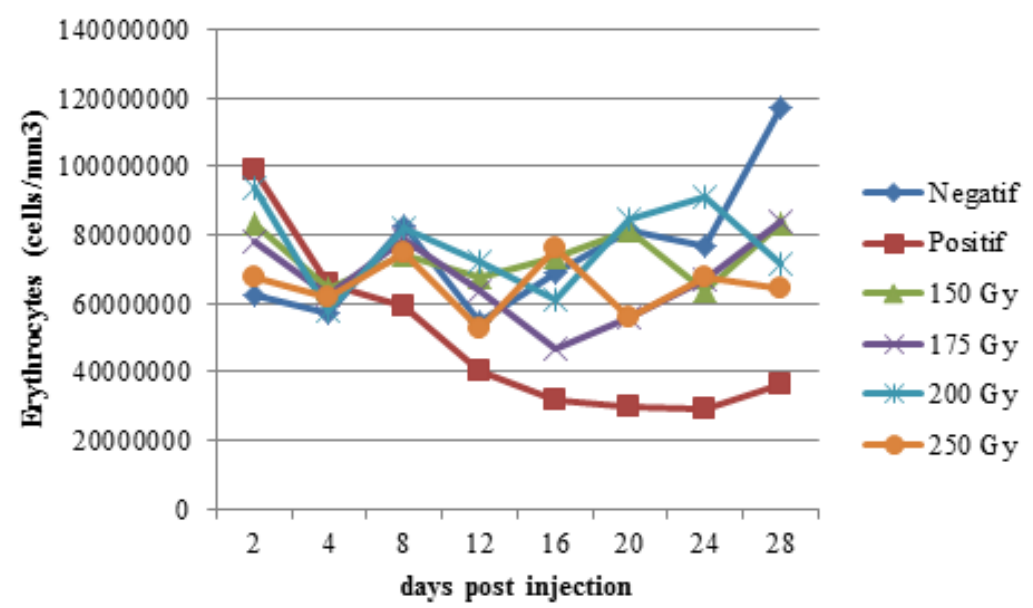

Figure 3. Erythrocytes number ofnegative control treatment, positive, 150, 175, 200 and 250 Gy

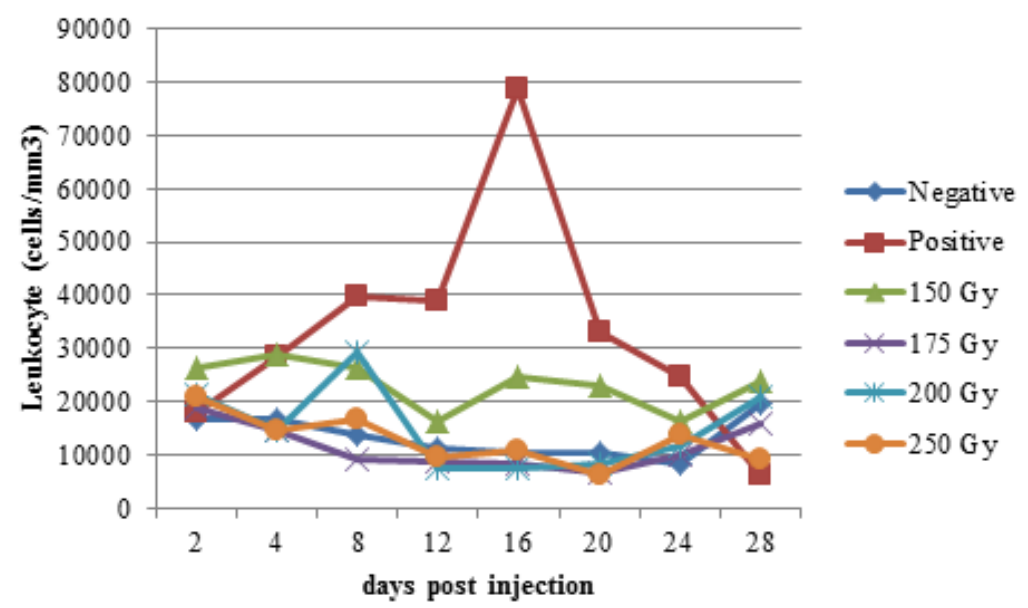

Figure 4. Mice leukocytes number of negative control treatment, positive, 150, 175, 200 and $250 \mathrm{~Gy}$

tions caused by $P$. berghei infection.

As seen in Figure 4 that among irradiated P. berghei treatment mouse, dose of 150 Gy showed a highest number of leukocytes that started on day 4. This result indicated that treatment of $150 \mathrm{~Gy}$ contains a parasite that has already weakened due to radiation dose rate of $740 \mathrm{~Gy} / \mathrm{h}$, thus potentially as an active vaccine (Syaifudin et 
al., 2008). Based on the results of this research it was known that dose of $150 \mathrm{~Gy}$ at a dose rate of $740 \mathrm{~Gy} / \mathrm{h}$ was the optimum dose to weaken the parasites. P. berghei treated with $175-250$ Gy supposedly died due to its high dose rate of irradiation.

\section{Analysis of Protein Profile}

Studies of protein profiles after irradiation in vaccine development are important aspect to know the purity of product as well as its safety as vaccine materials. When two proteins are covalently crosslinked due to irradiation or other causes, the gel migration patterns of both proteins shift in relation to the uncrosslinked proteins. Therefore, if antibodies, for example, that detect each target protein are available, the most straight forward method to detect the shift of the interacting proteins is by SDS-PAGE and Western blot analysis. Protein concentrations may change as a result of gamma-ray irradiation of either their structures or bonds. Changes can be caused by structure denaturation and protein degradation, as well as changes of deoxyribonucleic acid (DNA). This DNA change may lead to increase protein synthesis or formation of new proteins (Syaifudin, 2014). Protein profiling is an emerging independent subspecialty of proteomics that is rapidly expanding and providing unprecedented insight into biological events. Quantitative evaluation of protein levels can be accomplished with protein profiling, which shows unique expression patterns such as between experimental and control.

On gel SDS/PAGE after high-dose rate $(740 \mathrm{~Gy} / \mathrm{h})$ was delivered into red blood cells of mice of negative control group (without parasitic infections) there were 10 protein bands. These bands were corresponded to molecular weights of $132,125,112,97,88,74,59,45,37,33,21,18$ and $15 \mathrm{kDa}$, respectively (Figure 5 ). In positive control (with parasitic infections) there were 13 protein bands. Protein with molecular weights of 45,37 and $33 \mathrm{kDa}$ were not found in the negative control group. Therefore, these three bands are thought to be parasitic proteins or proteins related to immune system in mouse body as result of irradiation. Thicker bands were also observed that corresponded to the higher dose of irradiation. This is due to formation of new bands of protein induced by irradiation.

At the dose rate of $380 \mathrm{~Gy} / \mathrm{h}$ there were 13 bands seen on gel that were equal to positive control while only 10 bands in negative control. These proteins had the molecular weights of 133 , $104,91,80,72,58,46,39,34,30,18,14$ and 10 $\mathrm{kDa}$, consecutively. Whereas in control negative there were no protein bands with molecular weight of 39, 34 and $30 \mathrm{kDa}$ (Figure 6).

Our previously research found that protein profile in mouse blood infected with $P$. berghei was different between irradiated and non irradiated sample. Infected samples had higher number of bands compared to uninfected (control) sample indicating the presence of new proteins (imported) into host cell of malaria. Irradiation may

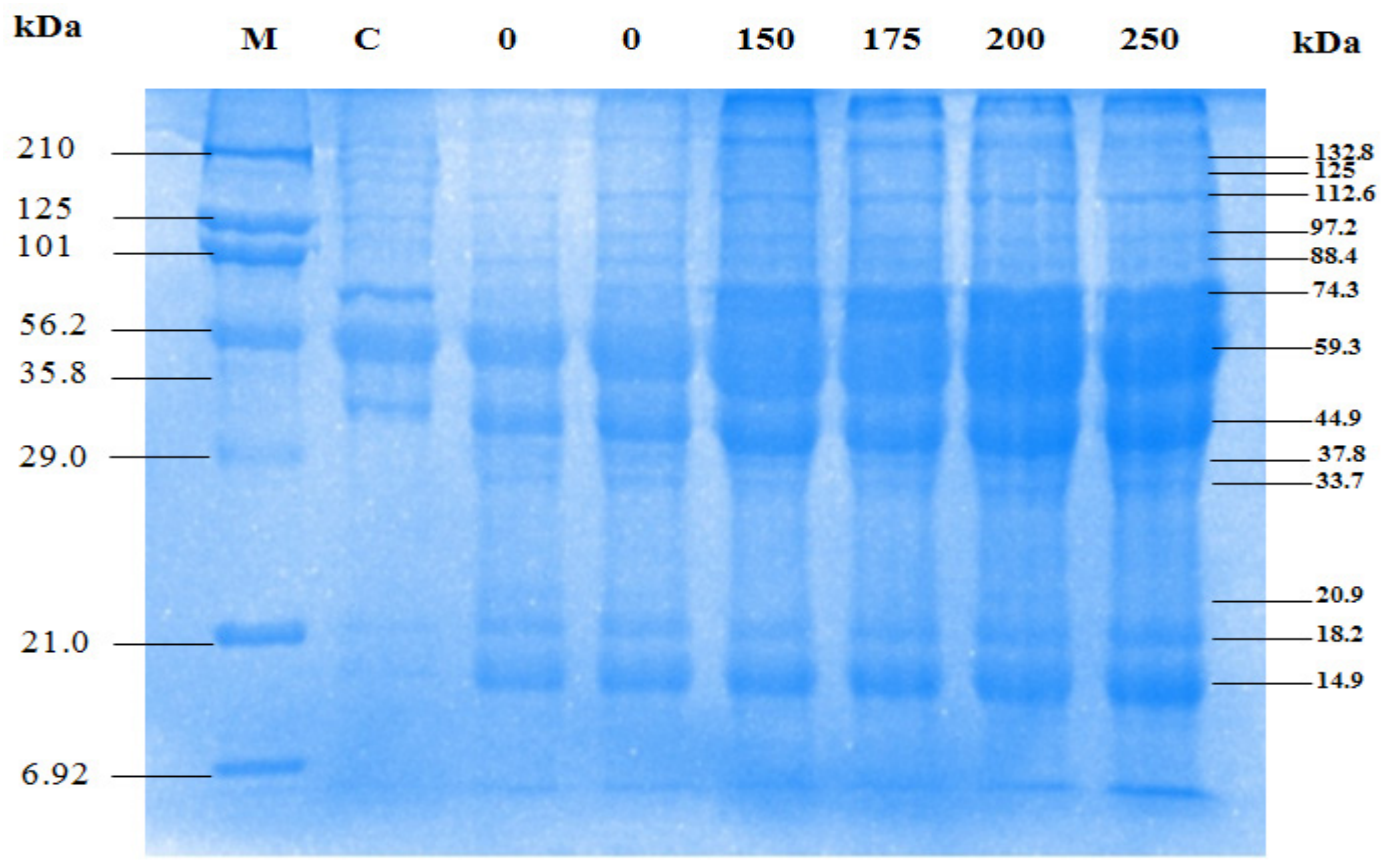

Figure 5. Profile protein in blood after irradiation at the high dose doses ( $740 \mathrm{~Gy} /$ hour) before injected into mouse. $\mathrm{M}=$ marker; $\mathrm{C}=$ negative control; $0=$ positive control; $150-250=$ dose of $150-250 \mathrm{~Gy}$ 
also cause the appearance of new proteins. Profile protein was also affected by the percentage of parasite in the blood, the stages of the life cycle of parasit, species of parasit that infected blood, and certainly dose of irradiation (Syaifudin et al., 2013).

According to Cortes et al., (2003) that a protein of P. berghei has molecular weight of 45 $\mathrm{kDa}$. That protein influences on the parasit infection and the mediation of parasite to penetrate the membranes of red blood cells. In 2004, specifically protein of $P$. berghei MSP7 (merozoites surface protein 7) was isolated by recombinant (Tewari et al., 2004). Research by Tewari et al., (2004) showed the MSP7 that found in P. berghei has a $42 \mathrm{kDa}$ molecular weight. MSP7 is a protein found in $P$. yoelii, $P$. berghei and $P$. falciparum. MSP7 is not protein that causes the death of the parasite but affecting its growth where growth is slower than the wild type. Subsequent studies that have been done by Bagai, Pawar \& Kumar (2010) showed that a protein antigen of $P$. berghei has molecular weights of 43 and $48 \mathrm{kDa}$. Protein of $48 \mathrm{kDa}$ is an immunogenic response and has higher molecular weight than the $43 \mathrm{kDa}$. Based on the results obtained in this research, protein with molecular weights of $45 \mathrm{kDa}$ and $39 \mathrm{kDa}$ were thought can be protein of $P$. berghei.

Activation key to the emergence of serine protease is MSP. This protein as pure enzyme migrated as bands with SDS-PAGE analysis with molecular weight of about $30 \mathrm{kDa}$ or $37 \mathrm{kDa}$ (Akuba \& Amlabu 2013; Wickham et al., 2003). Research by Yahya \& Kadir (2013) on protein profile analysis with SDS-PAGE of $P$. berghei of erythrocytes stage found proteins with the sizes of $120,60,30$ and $14 \mathrm{kDa}$. Protein with 30 $\mathrm{kDa}$ of size is protein that control (inhibit) the growth of $P$. berghei of intraerythrocytes phase (Yahya \& Kadir 2013). Based on the results of our study, protein with sizes of 37, 34, 33 and 30 $\mathrm{kDa}$ were suspected as protease protein that inhibit the growth of malaria parasit. Proteins with a molecular weight of 43,35 and $30 \mathrm{kDa}$ were not seen in the negative control. Therefore these proteins were thought to be proteins of $P$. berghei or antibodies. Research stated that protein with a molecular weight of 43 is the protein of $P$. berghei (Tewari et al., 2004; Bagai, Pawar \& Kumar 2010). Protein with molecular weight of $35 \mathrm{kDa}$ is serine protease and $30 \mathrm{kDa}$ of size is a protein that control (inhibit) the growth of $P$. berghei in intraerythrocytes stage (Akuba \& Amlabu 2013; Wickham et al., 2003)

Protein profiling at days post irradiation found that there was no alteration in bands on SDS-PAGE for negative control group. However in the positive control there was an alteration in bands with the disappearance of some bands that may be due to the destruction of red blood cells of mice (Figure 7). P. berghei at erythrocytic stage that attenuated by irradiation would be a non-recombinant inactive vaccine (Syaifudin et al., 2008). This type of vaccines needs to be challenged by injecting wild type of $P$. berghei (non irradiated parasit). New bands appeared after irradiation at doses of $150-250$ Gy beside due to $P$. berghei protein, it also as an antibody protein. An-

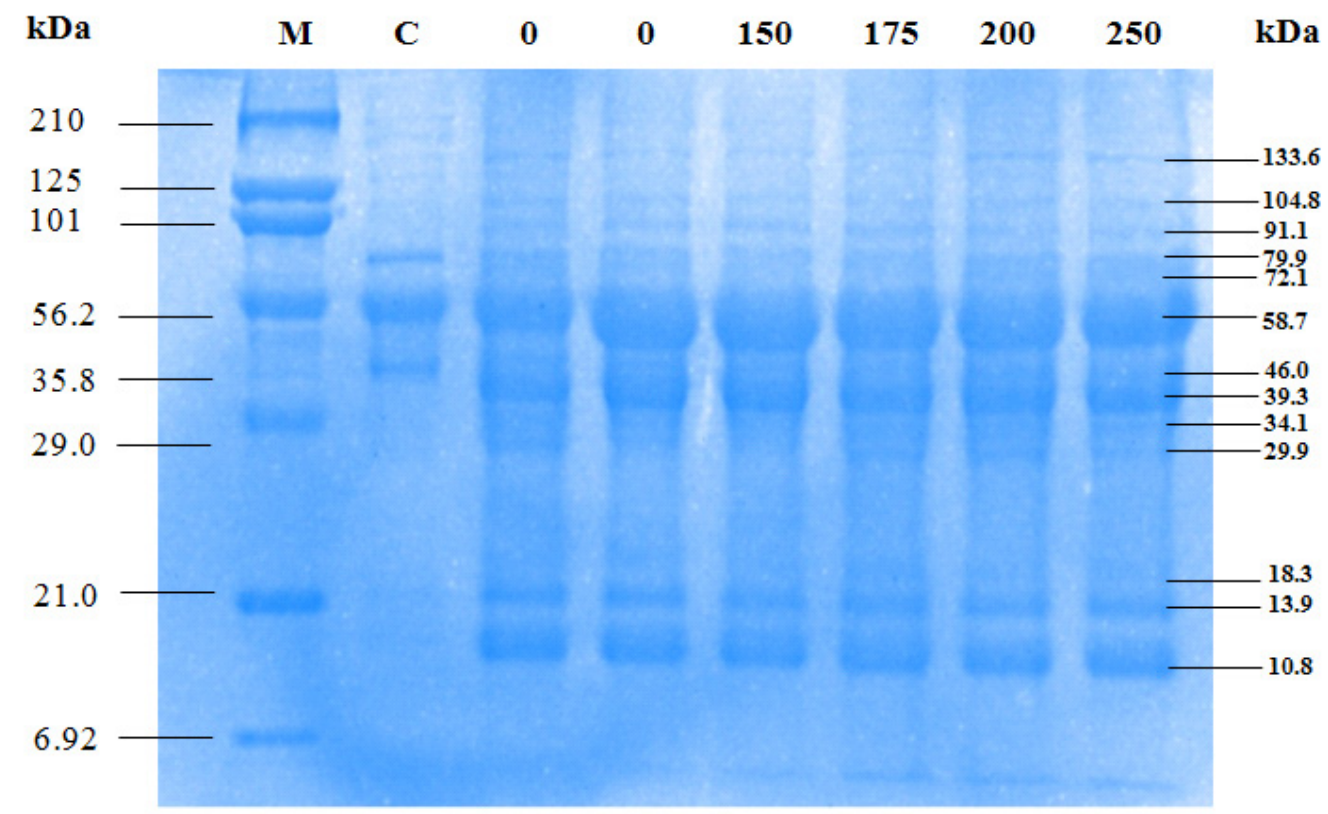

Figure 6. Profile protein after irradiation at the low dose doses (380 Gy/hour) before injected into mouse; $\mathrm{M}=$ marker; $\mathrm{C}=$ negative control; 0 = positive control; $150-250=$ dose of $150-250 \mathrm{~Gy}$ 
tibodies formed as immune response of mouse may result in memory antibody of $P$. berghei. Our results indicated that new protein was memory protein that may destroy $P$. berghei as an antigen.

For positive control, we analyzed the profile of protein of $P$. berghei from day 2 to 16 . At day 2 to 10 the molecular weights of protein were decreased. Molecular weight of proteins of negative control were 59, 44, 37, 12, 9 and $8 \mathrm{kDa}$. At day 2 there was a same in the weight of molecular between positive and negative controls. At day 12 to 16 the molcular weight only consisted of 36 , $30,12,9$ and $8 \mathrm{kDa}$ (Figure 8). Bands that disappeared was though due to the destroyed erythrocytes. Protein with sizes of 36 and $30 \mathrm{kDa}$ were both did not seen in negative control and still appeared till day 16.

Protein with a size of $\pm 43 \mathrm{kDa}$ was predicted as erythrocytic cell protein (antibody) of mouse because it disappeared during days of

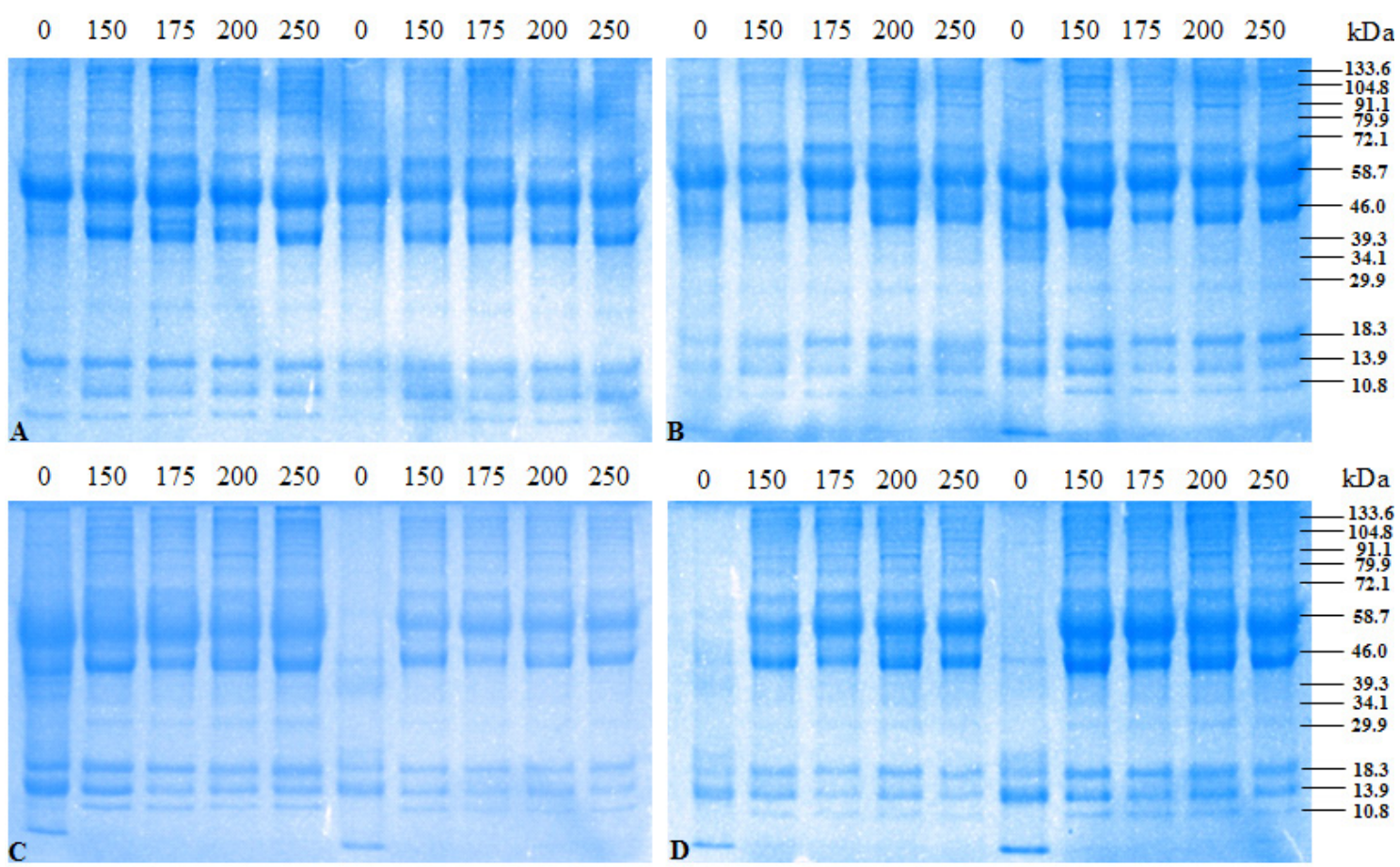

Figure 7. Protein profile in blood of the positive control mouse blood post infections with 150, 175, 200, 250 Gy irradiated P. berghei at days of (A) 3 and 4; (B) 6 and 8; (C) 10 and 12; (D) 14 and 16 post infections

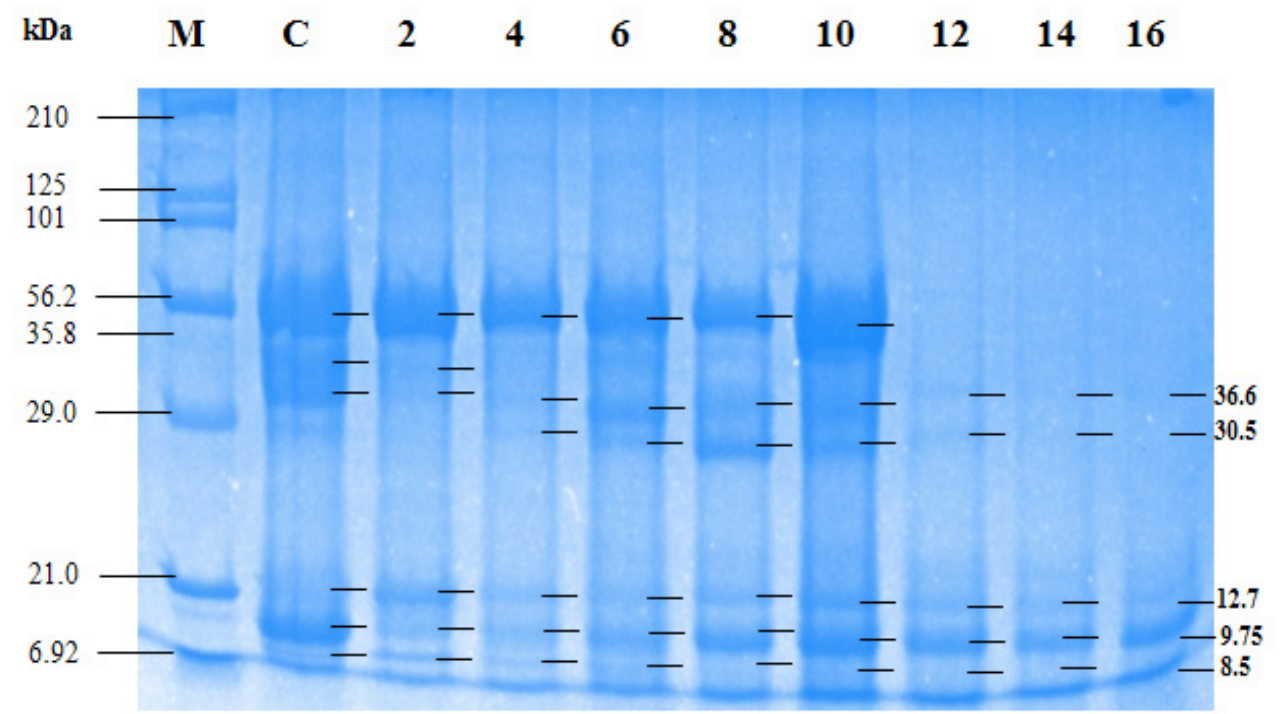

Figure 8. Alteration of protein profiles of $P$. berghei at day 2 to day 16 post injection. $\mathrm{M}=$ marker; $\mathrm{C}$ $=$ negative control 
Imam Rosadi, Mukh Syaifudin, Dewi Elfidasari / Biosaintifika 8 (2) (2016) 155-164

observations. These proteins were not surely as specific protein because there were about 400 putative proteins in $P$. berghei. These 400 proteins were corresponding to about $8 \%$ of genes, of which 225 proteins were related to the virulence of parasit and 160 proteins were included in host erythrocytes and parasit interaction (Marti et al., 2004). This suggested that futher research is needed to make sure the type of protein such as with western blotting method.

\section{CONCLUSION}

The research showed that there was no significantly differences result of $740 \mathrm{~Gy} / \mathrm{h}$ dose rate at doses of $150,175,200$ and $250 \mathrm{~Gy}$ to erythrocytes, leukocytes and body weight of negative control mouse group. Dose of $150 \mathrm{~Gy}$ was optimal dose of irradiation to attenuate/inactivate parasites. Alteration of profile protein was characterized by the additional amounts of bands with molecular weight of $37-30 \mathrm{kDa}$ allegedly as MSP of $P$. berghei and/or antibodies in mouse body.

\section{ACKNOWLEDGMENT}

Authors thank to Dr. Puji Budi Setia Asih and Dr. Din Safruddin from the Eijkman Institute for Molecular Biology for providing the $P$. berghei infected mouse blood. Apreciate is also given to Teja Kisnanto, staff of the Division of Nuclear Medicine Technique and Radiation Biology, Center for Technology of Radiation Safety and Metrology, National Nuclear Energy Agency, for technical help.

\section{REFERENCES}

Akuba, B. O. \& Amlabu, E. (2013). Purification and biochemical characterization of serine proteases from Plasmodium berghei NK-65. International Journal of Science, 2(2), 104-112.

Asih, P. B. S., Syahrani, L., Rozi, I. E.P., Pratama, N. R., Marantina, S. S., Mangunwardoyo, W., Hawley, W., Laihad, F., Shinta., Arsyad, D.S., Sukowati, S., Lobo, N.F., Syafruddin, D. (2012). Existence of the $r d l$ mutant alleles among the anopheles malaria vector in Indonesia. Malaria Journal, 11(1), 1.

Autino, B., Corbett, Y., Castelli, F. \& Taramelli, D., (2012). Pathogenesis of malaria in tissues and blood. Mediterranean Journal of Hematology and Infectious Diseases, 4(1), 1-12.

Autino, B., Noris, A., Russo, R., Castelli, F. (2012). Epidemiology of malaria in endemic areas. Mediterranean Journal of Hematology and Infec- tious Diseases, 4(1), 2012060.

Bagai, U., Pawar, A., Kumar, V. (2010). Antibody responses to 43 and $48 \mathrm{kDa}$ antigens of bloodstage Plasmodium berghei in Balb/c mice. Journal of Parasitic Diseases, 34(2), 68-74.

Basir, R., Fazalul-Rahiman, S.S., Hasballah, K., Chong, W.C., Talib, H., Yam, M.F., Jabbarzare, M., Tie, T.H., Othman, F., Moklas, M.A.M., Abdullah, W.O. (2015). Plasmodium berghei ANKA infection in ICR mice as a model of cerebral malaria. Iranian Journal Parasit, 7(4), 62-74.

Cortes, G. T., Winograd, E., Wiser, M. F. (2003). Characterization of proteins localized to a subcellular compartment associated with an alternate secretory pathway of the malaria parasite. Molecular and Biochemical Parasitology, 129(2), 127135.

Crompton, P. D., Pierce, S. K., Miller, L. H. (2010). Advances and challenges in malaria vaccine development. Journal of Clinical Investigation, 120(12), 4168-4178.

Darlina, \& Tetriana, D. (2006). Pengaruh irradiasi gamma pada Plasmodium berghei terhadap daya tahan mencit. Retrieved from http://www. batan.go.id/NHC/dokumen/devita4.pdf.

Delves, M., Plouffe, D., Scheurer, C., Meister, S., Wittlin, S., Winzeler, E.A., Sinden, R.E. and Leroy, D., (2012). The activities of current antimalarial drugs on the life cycle stages of Plasmodium: a comparative study with human and rodent parasites. PLOS Medicine, 9(2), 165-176.

Demicheli, M. C., Reis, B. S., Goes, A. M., De Andrade, A. S. R. (2006). Paracoccidioides brasiliensis: attenuation of yeast cells by gamma irradiation. Mycoses, 49(3), 184-189.

Hill, A. V. (2011). Vaccines against malaria. Journal of Biological Sciences, 366(1579), 2806-2814.

Hoffman, S.L., Goh, L.M.L., Luke, T.C., Schneider, I., Le, T.P., Doolan, D.L., Sacci, J., Vega, Pdl., Dowler, M., Paul, C., Gordon, D.M., Stoute, J.A., Church, L.W.P., Sedegah, M., Heppner, D.G., Ballou, W.R., Richie, T.L. (2002). Protection of Humans against Malaria by Immunization with Radiation-Attenuated Plasmodium falciparumSporozoites. Journal of Infectious Diseases, 185(8), 1155-1164.

Jobe, O., Lumsden, J., Mueller, A.K., Williams, J., SilvaRivera, J., Kappe, S.H.I., Schwenk, R.J., Matuschewski, K., Krzych, U. (2007). Genetically-attenuated Plasmodium berghei liver-stages induce sterile protracted protection that is mediated by MHC class I dependent IFN- $\gamma$ producing CD8+ T cells. Journal of Infectious Diseases, 196(4), 599-607.

Krishna, S., Bharti, P.K., Chandel, H.S., Ahmad, A., Kumar, R., Singh, P.P., Singh, M.P. Singh, N., (2015). Detection of mixed infections with Plasmodium spp. by PCR, India, 2014. Emerging Infectious Diseases, 21(10), 1853.

Lamikanra, A.A., Brown, D., Potocnik, A., CasalsPascual, C., Langhorne, J., Roberts, D. J. 
(2007). Malarial anemia: of mice and men. Blood, 110(1), 18-28.

Marti, M., Good, R.T., Rug, M., Knuepfer, E., Cowman, A.F. (2004). Targeting malaria virulence and remodeling proteins to the host erythrocyte. Science, 306(5703), 1930-1933.

Ministry of Health Republic Indonesia (KEMENKES). (2011). Epidemiologi Malaria di Indonesia. Jakarta : Bakti Husada.

Mlambo, G. \& Kumar, N. (2008). Transgenic rodent Plasmodium berghei parasites as tools for assessment of functional immunogenicity and optimization of human malaria vaccines. Eukaryotic Cell, 7(11), 1875-1879.

Spiering, M. J. (2015). Primer on the Immune System : current reviews. J Alcohol Res, 37(2), 171-175.

Syaifudin, M. (2014). Peranan Faktor Imun dan Profil Protein dalam Penelitian dan Pengembangan Vaksin Malaria Iradiasi. Biosaintifika: Journal Biology \& Biology Education, 6(1), 8-17.

Syaifudin, M., Nurhayati, S., Tetriana, D. (2008). Pengembangan vaksin malaria dengan radiasi pengion. Dalam: Prosiding Seminar Nasional Sains dan Teknologi-II. Lampung, 17-18 November 2008. Lampung: SemnasSaintek-II.

Syaifudin, M., Tetriana, D., Darlina, Nurhayati, S. (2013). Studies on the protein profiles of gamma ray induced blood stage of Plasmodium berghei for developing candidate of malaria vaccine. International Journal of Engineering Research and Applications, 3(1), 314-319.

Tetriana, D., Darlina., Armanu., Syaifudin, M. (2008). Pengaruh radiasi gamma terhadap profil protein Plasmodium berghei stadium eritrositik. Dalam: Prosiding Seminar Nasional Keselamatan, Kesehatan dan Lingkungan IV dan International Seminar on Occupational Health and Safety I. Buku 1. Depok, 27 Agustus 2008. Depok: Int on Occup Health and Safe I. pp. 282292.

Tewari, R., Ogun, S.A., Gunaratne, R.S., Crisanti, A., Holder, A.A. (2004). Disruption of Plasmodium berghei merozoite surface protein 7 gene modulates parasite growth in vivo. Blood, 105(1), 394-396.

Wickham, M. E., Culvenor, J. G., Cowman, A. F. (2003). Selective inhibition of a two-step egress of malaria parasites from the host erythrocyte. Journal of Biological Chemistry, 278(39), 3765837663.

Yahya, M.F.Z.R. \& Kadir, R.A. (2013). Palm oil supplementation prevents further tyrosine dephosphorylation of erythrocytes $30-k d a$ protein during Plasmodium berghei infection. Journal of Pharma and Bio Sciences, 3, 131-137.

Zuzarte-Luis, V., Mota, M. M., Vigário, A. M. (2014). Malaria infections: what and how can mice teach us. Journal of Immunological Methods, 410, 113-122. 